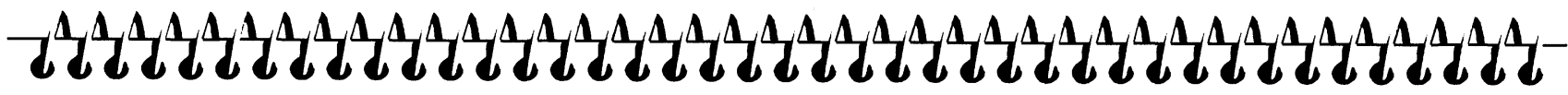

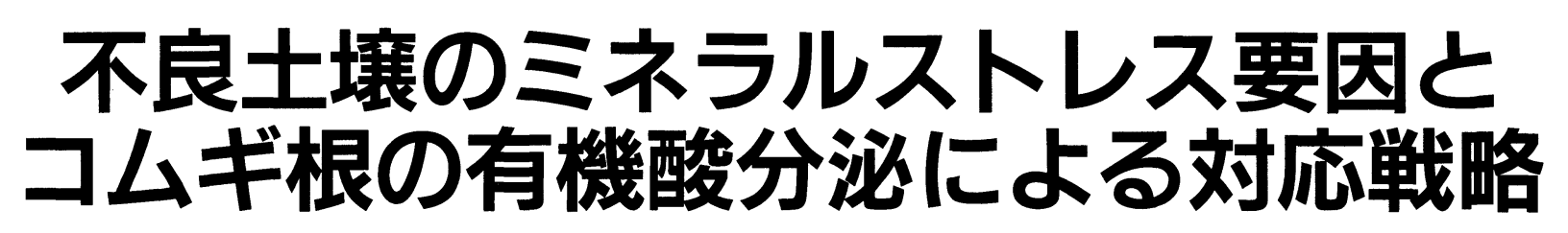

小島 邦彦

東北大学農学部*

酸性ならびにアルカリ性両不良土壤における光れ光れのアル ミニウム過剩と鉄欠乏は, 植物生育に対する主要なストレス 要因となっている。これらのストレスを回避するために, 植 物は根から分泌する有機酸類により, 金属をキレート化する 仕組みを有することが明らかにされている.コムギ作物では，

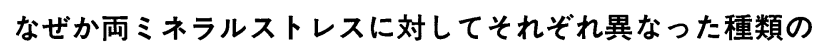
有機酸を分泌するという対応戦略がとられている。こうした 分泌物質の使い分けの生理的意義は一体どのようなところに あるのだろうか.

酸性土壤ならびにアルカリ性土䁃は，それぞれ世界の 全耕地面積のおよそ 3 分の 1 を占めるといわれ, 作物生 産に多くの課題を投げかけている. 自然界において, 特 にストレス而性の植物は, これらの不良土壌環境に対し てそれぞれ特有の適応能力を発揮しながら生活を営んで いる.このような植物の適応機構は, その進化の過程で 獲得されたものであり, 生物科学の立場からは, 常に目 的論的ならびに因果論的という 2 つ側面から考察を加 えることができる.こうした点を念頭におきながら，代 表的な 2 つの不良土畩環境で起こる金属関与のストレス

*現(株) 渡辺採種場研究部
に際して, 異なる種類のキレーターを根から分泌して, 臨機応変に対処するという「コムギの水際作戦」をとり 上げる.

本稿では, まず土壤の側から，バンド（酸化アルミニ ウム）質酸性土㙥ならびに石灰質アルカリ性土裹におけ るミネラルストレス要因と, それらによる植物生育阻害 の問題点について整理し, 次いで植物の側から, アルミ ニウム $(\mathrm{Al})$ 過剰ならびに鉄 $(\mathrm{Fe})$ 欠乏というストレス要 因に応答して，それぞれ異なった有機酸類を分泌するコ ムギ根の生理的特性に言及し, 最後に土壌と植物の立場 から, 両不良土袞環境において $\mathrm{Al}$ の解毒または $\mathrm{Fe}$ 養分 の供給を通して, 根分泌物質の使い分けを行なうコムギ 植物の対応戦略の意義について考察する.

\section{酸性土壤とアルカリ性土壤における ミネラルストレス要因}

バンド質酸性土壤は, 我が国のような多雨で塩基の流 亡の著しい地域に広く発達し, その作物生育阻害の最大 要因は, 土壤 $\mathrm{pH}$ の低下に伴って微量に溶出してくる $\mathrm{A} 1$ にある. 他方, 石灰質アルカリ性土壤は, 対照的に諸 
大陸の乾燥または半乾燥地帯に石灰に富む塩類土壌とし て広く発達し, 土壤 $\mathrm{pH}$ の 7 8 付近で難溶化に伴う $\mathrm{Fe}$ 要素欠乏が一大ストレス要因となっている.

さて,この $\mathrm{Al}$ と $\mathrm{Fe}$ 両金属元素は, 土㙵中での存在形 態や理化学性などの面で類似点が多い。たとえば，地球 表部の構成元素のうち, 重量百分比で $\mathrm{Al}$ は, 酸素, 珪素 についで約 $8 \%$ と 3 番目に, $\mathrm{Fe}$ は約 $5 \%$ と 4 番目に多 い元素として存在し, 粘土の構成成分や種々の複合物な どとして土壌形成の骨格をなしている，また，両金属元 素はともに $\mathrm{pH} 4$ 以下の水溶液では 3 価の陽イオンとし て存在するが，弱塩基で徐々に中和してゆくといずれも 水酸化物のゲル状沈澱を生じる。

しかし, このように多くの点で類似する両元素は, 植 物の生育に対しては害と益のそれぞれまったく異なった 影響をもたらす.すなわち, Al はカチオンとして細胞壁 のペクチンや細胞膜脂質のリン酸基に結合するとされ, 酸性土㙵では根端の形態的損傷が真っ先に観察される。 他方, 必須微量要素である Fe はアルカリ性土壤では難 溶化し，その要素欠乏によりクロロフィル合成が妨げら れ，緑葉にクロロシスが容易に発現する。つまり， $\mathrm{Al}$ イ オンは酸性土壤で濃度過剩により, 他方 $\mathrm{Fe}$ 要素はアル カリ性土壌でその欠乏により，それぞれ地下部の根と 地上部の葉にというように，対照的に生理的障害をもた らす。

土壤中における $\mathrm{Al}$ または $\mathrm{Fe}$ の存在形態は, 遊離イ オン, 交換性イオン, 遊離の酸化物または水酸化物, 粘 土鉱物成分あるいは腐植複合体などときわめて多様であ り, それらの量比は土壌の物理的化学的条件に応じて複 雑に変化する. しかし, これらの中で植物のストレス要 因として直接的に大きく関わる化学形態のものは，その ごく一部である。酸性土壤では，低 $\mathrm{pH}$ 下で微量に存在 する遊離 $\mathrm{Al}^{3+}$ イオンまたは交換性 $\mathrm{Al}$ イオンが最も重 要であり, 対応策としてはその毒性をいかに排除するか ということにある。この場合, Fe は微量ながら溶存状態 にあるので，栄養補給面ではむしろ好ましい，他方，ア ルカリ性土㙋では, 上記の各種形態 $\mathrm{Fe}$ の中で最も可給 化しやすい Fe 源である遊離水酸化物, 特に低結晶性の フェリハイドライト $(\mathrm{Fe}(\mathrm{III}))$ が激減しているので，こ れをいかに有効利用するかということである。この場合， $\mathrm{Al}$ は $\mathrm{Fe}$ 同様ほとんど不溶性の状態になっているので その毒性は問題にならない。

\section{|アルミニウム過剩ならびに鉄欠乏両ストレス下に おけるコムギ根による有機酸類の分泌}

このように, 酸性土壌の主要な阻害要因が水素イオン

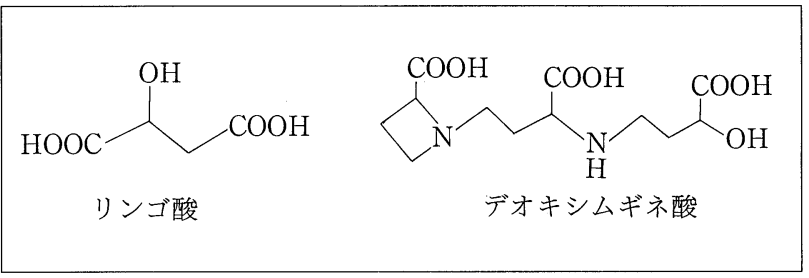

そのものではなく $\mathrm{Al}$ イオンにあるという背景のもと， 古くから作物に対する $\mathrm{Al}$ 関与の阻害や耐性に関わる研 究が数多くなされてきた. $\mathrm{Al}$ 而性機構に関しては, 生体 の内または外で働くいくつかのメカニズムが提唱されて いるが(1), 最近, 特に注目されているのが, 植物種によ ってクエン酸, リンゴ酸, シュウ酸などのカルボン酸が 根から培地に向けて放出され, $\mathrm{Al}^{3+}$ イオンが解毒, 排除 されるという機構である。

他方, アルカリ性土壌で問題となる Fe の欠乏に関し ては, イネ科植物根におけるムギネ酸類の分泌による対 応についての高城の一連の研究が注目される(2). $\mathrm{Fe}$ 欠 そストレス下でムギネ酸類が根から多量に分泌され, 根 圈の難溶性 Fe が可給化されて吸収, 利用されるという ものである. ムギネ酸類は, 分子量約 300 の酸性アミノ 酸(広義の有機酸)であり, 化学構造の一部を異にする 6 種類が知られている.

上述の $\mathrm{Al}$ イオン過剰ならびに $\mathrm{Fe}$ 欠乏のストレス双 方にわたり, その適応性もしくは耐性機構などについて 研究され, 比較的よく説明できると思われるのがコムギ 作物についてであり, そしてこのことが本稿の主題の植 物種としてとり挙げた理由でもある.

$\mathrm{Al}$ ストレスに応答して, コムギが根, 特に根端から分 泌するのはリンゴ酸であり, 水耕液中における $\mathrm{Al}^{3+}$ イ オンをキレート化する ${ }^{(3,4)}$. この $\mathrm{Al}$-リンゴ酸化合物は毒 性が低く,かつそのままの形では $\mathrm{Al}^{3+}$ イオンに比べて著 しく吸収されにくい.コムギは品種によっては $\mathrm{Al}$ に対 する耐性幅が 10 倍以上と比較的広い作物であるといわ れ，その耐性のものほど $\mathrm{Al}$ ストレスによるリンゴ酸の 分泌量は多くなる(図 1).

他方，同じコムギが Fe 欠乏ストレスに遭遇すると， 根端からデオキシムギネ酸が多量に分泌され, 難溶性 $\mathrm{Fe}$ (III)がキレート化される. 形成された $\mathrm{Fe}$-デオキシム ギネ酸化合物はその複合体 (錯体) の形で根に速やかに 吸収される. イネ科植物種間を通じてムギネ酸類の根分 泌量と $\mathrm{Fe}$ 獲得能との間には相関性が認められており, イネ科の中でもコムギはイネ, トウモロコシ, ソルガム などに比べてムギネ酸類をより多量に分泌する部類に入 る.

なお, Fe 欠乏条件下でのリンゴ酸分泌の可能性は, 根 


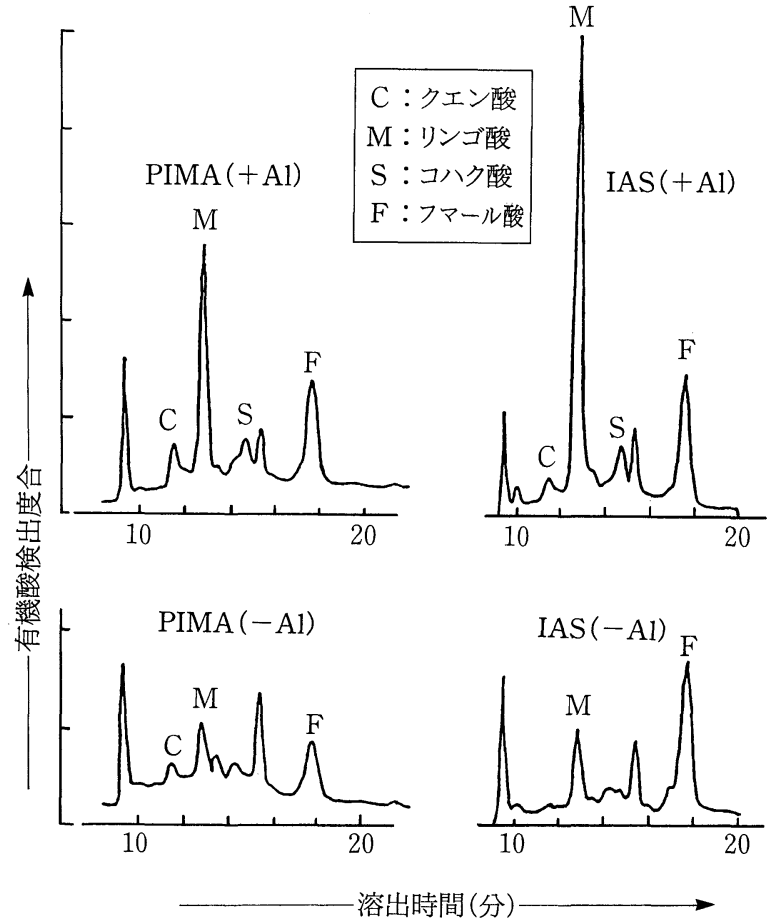

図 1 ロコムギ幼植物根から酸性溶液中に放出された有機酸 の HLPC における溶出パターン

文献 4) より改変. IAS：Al 耐性品種, PIMA：同感受性品種, $+\mathrm{Al}$ : アルミニウム添加, $-\mathrm{Al}$ : 同無添加. 無菌条件下におけるコ ムギの分泌物質として数種の有機酸が検出された. $\mathrm{A} 1$ ストレスに より特にリンゴ酸の放出量が増加するが，その度合いは $\mathrm{Al}$ 感受性 より耐性の品種で著しい.

分泌物質に起因する $\mathrm{Fe}$ 溶解活性が水耕液の酸性画分に ほとんど認められないことから，また逆に，Al ストレス 下でのムギネ酸の分泌の可能性は, $\mathrm{Al}$ の解毒効果が培養 液の塩基性画分に認められないことから，あるとしても きわめて低いものと考えられる。

\section{不良土壤におけるリンゴ酸または デオキシムギネ酸分泌による対応戦略}

不良土壤の根圈環境では常にいくつかのストレス要因 が関与し，厳密にはそれらが複雑に絡み合って植物生育 に障害を与える。とはいえ，上述のように $\mathrm{Al}$ 阻害と $\mathrm{Fe}$ 欠乏がそれぞれ主要な制限因子であるというのが一般的 であって，ここではその前提に立ってこれまでの話を両 不良土壌にもどしてみよう。すると，コムギは同じ金属 キレーターであるリンゴ酸とデオキシムギネ酸をそれぞ れ酸性ならびにアルカリ性両不良土壤で分泌するという ことになる。では，こうして分泌された 2 種類のキレー 卜性有機酸を，それぞれが置かれた土壤環境の中で，一 方は $\mathrm{Al}$ の解毒化に，他方は $\mathrm{Fe}$ の可給化にと使い分けを する対応戦略は，一体コムギにとって合目的にどのよう

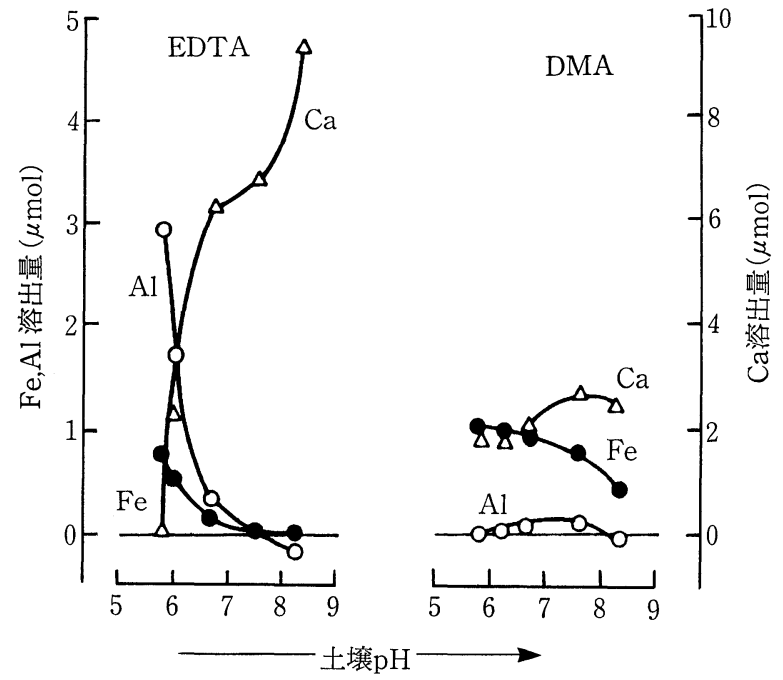

図 2 ロデオキシムギネ酸(DMA)ならびに EDTA によるア ルミニウム, 鉄およびカルシウムの溶出と土壤 $\mathrm{pH}$ との関係 文献 2) より改変. 黒ボク土壤を用い $\mathrm{pH}$ は消石灰で調整。土壤： 溶液 $=1: 20,30^{\circ} \mathrm{C}$ で 3 時間振とう, 溶出量 : $\mu \mathrm{mol} / 5 \mu \mathrm{mol}$ キレー 夕ー

な利益があるのだろうか.

高城らは，異なる $\mathrm{pH}$ に調整した黒ボク土壌の懸濁液 にムギネ酸類を含む種々の金属キレーターを加えて， $\mathrm{Al}, \mathrm{Fe}$ および $\mathrm{Ca}$ (カルシウム)の土壤からの溶出状況を 調べた ${ }^{(2)}$. EDTA は酸性側では $\mathrm{Al}$ を，アルカリ性側で は $\mathrm{Ca}$ を多量溶出したが， $\mathrm{Fe}$ の溶出は比較的少なく，そ の傾向はアルカリ側で顕著であった。他方，デオキシム ギネ酸はどの $\mathrm{pH}$ 領域においても $\mathrm{Al}$ はほとんど溶出し ないが，土壌中に存在の $\mathrm{Fe}$ (III) が Ca に比べて少量に過 ぎないにもかかわらず，Fe の相当量を溶出した（図 2).

もう一つのコムギの根分泌物であるリンゴ酸に関連し ては，腐植質火山灰土壤を供試してのリンゴ酸やクエン 酸による $\mathrm{Al}$ 抽出実験，石灰質土壤に扔ける根分泌のク エン酸による $\mathrm{Ca}$ のキレート化などの研究報告，あるい はクエン酸による土壤や肥料からのリン酸抽出の実験結 果などから類推できる(5).これらを総合すると，キレー 卜化合物形成は系の $\mathrm{pH}$ に依存するところが大きく，ク エン酸同様，リンゴ酸も図 2 の EDTA と類似の反応様 式をとるものとみられる，すなわち，リンゴ酸の土壌成 分の $\mathrm{Al}$ または $\mathrm{Fe}$ との反応性は酸性側で高く,アルカリ 側では両金属イオンは不溶性となり，Ca との反応性が 高くなる。

結局，リンゴ酸は，バンド質酸性土壤では溶存する $\mathrm{Al}^{3+}$ イオンならびに土壤コロイドに吸着の交換性 $\mathrm{Al}$ イ オンを容易にキレート化し，石灰質アルカリ性土壤では 豊富に存在する $\mathrm{Ca}$ と優先的に結合する．他方，デオキ シムギネ酸は，バンド質土壤では $\mathrm{Al}$ との反応性は比較 


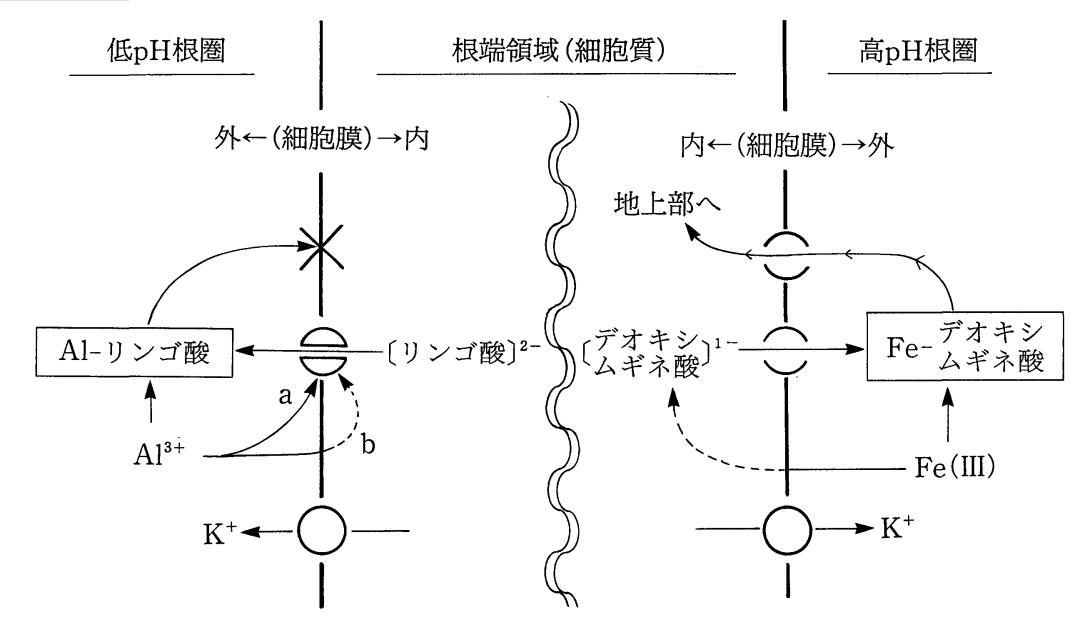

図 3 曰根圏におけるアルミニウム過剩ならびに鉄欠乏両ストレスに対するコムギ根の有機酸類の分泌による対応戦略（想像模 式図)

酸性根圏における $\mathrm{Al}^{3+}$ イオンが, 直接的 $(\mathrm{a})$ または間接的 $(\mathrm{b})$ に細胞膜チャンネルに作用してリンゴ酸イオンが放出される*. 根圈で形成さ れた Al-リンゴ酸化合物は毒性が低く，根内には吸収されにくい(図左側)，アルカリ性根圏における Fe 欠乏のシグナルにより生合成系が 始動し，生成されたデオキシムギネ酸が放出される。根圈で難溶性 $\mathrm{Fe}$ (III) と反応して形成された $\mathrm{Fe}-$ デオキシムギネ酸化合物は輸送タン パク質により細胞膜内に搬入される (眓右側) ${ }^{* *}$.いずれの場合も,有機アニオンと当量のカリウムイオン $\left(\mathrm{K}^{+}\right)$が共輸送により放出されて細 胞内の電気的ポテンシャルが保たれる.

*文献 3）より改変. **詳しくは文献 6）を参照.

的低いが，石灰質土壌では多量の $\mathrm{Ca}$ の中にあって $\mathrm{Fe}$ と効率的にキレート化合物を形成するということができ る.こうした有機酸と土壤ミネラルとの反応特異性に は，単に生成定数といった理化学性のみならず，たとえ ば土壤中におけるミネラル(塩基や金属)の物理的・化学 的存在形態や，金属溶出に先立つ有機酸類の鉱物表面の 吸着反応など, 他の要因が複雑に関与していると考えら れている。

ここで注目されるのは，リンゴ酸もデオキシムギネ酸 も常時構造的に少量放出されるものではなく, ミネラル ストレスや気温など環境の変化に応答して, 根端から集 約的に分泌されることである。これは，ストレスに最も 鋭敏な根端部分に効率的な $\mathrm{Al}$ の解毒あるいは $\mathrm{Fe}$ の可 給化をもたらすと同時に，代謝産物の体外放出によるい たずらな消耗や土壌微生物による分解を回避するための 一つの自衛手段にもなっているように思われる.

$*$

コムギにおける有機酸類の根分泌をめぐって，(1)酸性 ならびにアルカリ性両不良土壤におけるミネラルストレ ス要因，(2)両ストレスに対応した異なる種類の有機酸 類の分泌，(3)不良土壌における金属のキレート化による 有機酸効果の順に述べてきたが，最後にこれらを総合的 に整理してみると次のようにまとめることができる(図 $3)$.
コムギ根は，バンド質土壌ではその低 $\mathrm{pH}$ 条件下で主 要な阻害因子となっている $\mathrm{Al}$ イオンのストレスに応答 してリンゴ酸を分泌する，根端表面付近の根圈土壇にお いて,リンゴ酸は $\mathrm{Al}$ をキレート化し, 毒性が低くかつ吸 収されにくい形態に変えて, $\mathrm{Al}$ 害から根を守る。他方, 同じコムギが石灰質土壤の高 $\mathrm{pH}$ の条件下で $\mathrm{Fe}$ 欠乏に 陥ると，リンゴ酸ではなくデオキシムギネ酸を活発に合 成，分泌する．この根分泌物質により，根圏土畩中の難 溶性 $\mathrm{Fe}$ が効率的にキレート化され，速やかに生体内に とり込まれる。

リンゴ酸もデオキシムギネ酸も天然の金属キレーター なので，両者が仮に逆の土壌環境で分泌されるとしたら ぞうなるであろうか。ムギネ酸類は酸性土壌に溶存する $\mathrm{Al}$ イオンに対してはキレート能は低く,リンゴ酸に比べ て解毒効果は明らかに劣るであろう。他方，リンゴ酸は その大部分が塩基性土壤に豊富に含まれる $\mathrm{Ca}$ と錯体を

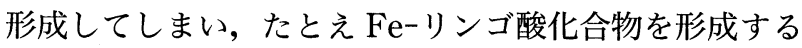
にしても，植物根による吸収はデオキシムギネ酸の場合 に比べて劣るので, $\mathrm{Fe}$ 要素の供給面では不利といわざ るを得ない.したがって, 酸性土畩- $\mathrm{Al}$ ストレスーリンゴ 酸分泌の組合せと，アルカリ性土㙥-Fe ストレスーデオ キシムギネ酸分泌の組合せにおいて，それぞれ有機酸の キレート反応特性がはじめて生かされる，こうしたとこ ろに，キレート効果の特性をふまえたコムギの両有機酸 使い分けの戦略的意義があると想像している. 
なお, 有機酸分泌関与の $\mathrm{Al}$ 而性機構に関する分子・遺 伝子レベルでの研究は進展著しいものの, まだ想像の 域を出ず(3)，ムギネ酸分泌のそれ(6)に先行されている感 がある．両者の耐性機構には比較の対象となる局面が多 いが，その論議はもう少し先のことになるように思われ る.

文献

1）松本英明：“低pH土壌 と植物”, 日本土㙥肥料学会編, 博友社,
1994, p. 59 .

2）高城成一：“金属関連化合物の栄養生理”, 日本土壊肥料学会 編, 博友社, 1990, p. 5.

3) E. Delhaize \& P.R. Ryan : Plant Physiol., 107, 315 (1995).

4）小島邦彦, 宮澤道雄, 佐々木瑞雄, 大平幸次: 無菌生物, 17, 91 (1987).

5）南条正巳 : “土壤蓄積りんの再生・循環利用”, 農業環境技術研 究所, 1986, p. 43.

6) 森 敏 : 土肥誌, 71, No. 2 (2000), 印刷中.

\section{プロフィル}

阿部 尚樹（Naoki Abe） 昭和 36 年 6 月 15 日生 $<$ 略歴 $>$ 昭和 60 年北海道大学 農学部農芸化学科卒業/昭和 62 年同大 学大学院農学研究科修士課程修了/同年 サッポロビール(株)応用開発研究所研究 員/平成 6 年グレラン製薬(株)開発研究 センター研究員 $/ 8$ 年静岡県立大学食品 栄養科学部助手, 現在にいたる。平成 5 年農学博(北海道大学) <研究テーマと抱 負 $>$ 今なお新規生理活性物質を与え，ま た，発酵により食品に三次機能を付与す る，そんな微生物のもつ力を化合物の総 合的評価をもとに有効利用に結びつける ことく趣味>パソコン (Macintosh) で 遊ぶこと

赤澤 堯（Takashi Akazawa） Vol. 35, No. 9, p. 616 参照

赤田 倫治（Rinji Akada）昭和 36 年 1 月 22 日生 <略歴> 1983 年広島大学理 学部生物学科卒業 $/ 1985$ 年同大学大学 院理学研究科修士課程修了 (動物学) / 1988 年同大学大学院工学研究科博士課 程修了(工業化学) /同年同大学遺伝子実 験施設助手 / 1994 年山口大学工学部助 教授, 現在にいたるく研究テーマと抱 負>遺伝学の酵母とお酒の酵母を両立さ せること.つまり, ょく学びょく遊ぶこ と<趣味>山, 大工

荒井 綜一 (Soichi Arai) 昭和 10 年 10 月 29 日生 <略歴>昭和 34 年東京大 学農学部農芸化学科卒業/同年森永製菓 (株) 入社 $/ 42$ 年東京大学農学部助手 $/$ 53 年同助教授 $/$ 平成 3 年同教授 (農芸化 学科食糧化学講座) $/ 8$ 年東京大学定年 退官 $/ 9$ 年東京農業大学応用生物科学部
教授, 現在にいたるく研究テーマと抱 負>機能性食品科学と味覚分子生物学 <趣味>宝塚歌劇

有富 和生 (Kazuo Aritomi) 昭和 30 年 7 月 17 日生 $<$ 略歴 $>$ 昭和 54 年山口大 学農学部農芸化学科卒業/同年山口県商 工指導センター勤務 $/ 63$ 年山口県工業 技術センター/平成 11 年山口県農業技 術センター, 現在にいたるく研究テーマ と抱負 $>$ 付加価值のある発酵食品の開発 $<$ 趣味 $>$ 写真撮影, サッカー

石田 宏幸（Hiroyuki Ishida）昭和 46 年 10 月 27 日生 $<$ 略歴>平成 6 年東 北大学農学部農芸化学科卒業 $/ 11$ 年同 大学大学院農学研究科農芸化学専攻博士 課程修了/同年同大学大学院農学研究科 助手, 現在にいたる.この間, 平成 $9 \sim 11$ 年日本学術振興会特別研究員<研究テー マと抱負>高等植物における Rubisco 分解の分子機構<趣味>ギャンブル全 般, 釣り, アクアリウム

宇田 泰三（Taizo Uda） 昭和 22 年 2 月 3 日生 <略歴> 1974 年九州大学大学 院工学研究科応用化学専攻博士課程修 了/1976 年米国ウィスコンシン大学博 士研究員 $/ 1984$ 年宇部興産(株)中央研 究所診断薬研究室室長/1991 年広島県 立大学助教授 / 1994 年同教授, 現在にい たる<研究テーマと抱負 $>$ 細胞工学・抗 体工学・生物物理化学に関連したテーマ を数グループに分けて走らせているく趣 味>読書, スポーツ鑑賞

小島 邦彦 (Kunihiko Ojima) 昭和 5 年 9 月 26 日生 $<$ 略歴 $>$ 昭和 28 年東北大
学農学部農芸化学科卒業後, 同大学大学 院農学研究科後期課程修了. 同大学助 手, 助教授を経て教授/平成 6 年定年退 職, (株) 採種実用技術研究所常務取締 役·研究部長, (株)渡辺採種場研究顧問, 現在にいたる。 この間, 1966〜 68 年力 ナダ国立科学研究所研究員, 1979 99 年 岩手大学大学院農学研究科非常勤講師 <趣味>囲碁

太田 啓之（Hiroyuki Ohta） 昭和 32 年 8 月 24 日生 <略歴> 1982 年神戸大学 農学部農芸化学科卒業/1987 年京都大 学大学院農学研究科食品工学専攻博士課 程修了 / 1988 年三井業際植物バイオ研 究所研究員 $/ 1989$ 年岡崎国立共同研究 機構基礎生物学研究所協力研究員 $/ 1991$ 年東京工業大学生命理工学部助手 $/ 1997$ 年同助教授, 現在にいたるく研究テーマ と抱負 $>$ 高等植物の葉緑体 (特に膜脂質) の形成と分解の機構，およびその生理的 意義について＜趣味>コーヒーを入れる こと

大西 浩平 (Kouhei Ohnishi) 昭和 35 年 4 月 11 日生 <略歴>昭和 58 年東京大 学理学部生物学科卒業 $/ 60$ 年同大学大 学院理学系研究科修士課程修了/平成 2 年同博士課程修了/同年早稲田大学人間 総合研究センター助手 $/ 5$ 年米国コール 大学ポストドクトラルフェローを経て, 7 年から(株)海洋バイオテクノロジー研 究所勤務, 現在にいたるく研究テーマと 抱負 $>$ 進化分子工学, 分子遺伝学 $<$ 趣 味>テニス

岡畑 恵雄 (Yoshio Okahata) Vol. 35, No. 9 , p. 616 参照 